31. Вирок Петропавлівського районного суду Дніпропетровської області від 26 липня 2018 р. у справі № 188/1672/16-к. Єдиний державний реєстр судових рімень. URL: http://www.reyestr.court.gov.ua/Review/75506395

32. Газдайка-Василишин І. Б. Некорисливі злочини проти власності: монографія. Львів: Львівський державний університет внутрішніх справ, 2012. 212 с.

33. Шульга А. М. Науково-теоретичне визначення видового об'єкту земельних злочинів через земельних правовідносин. Наука кримінального права в системі міждисииплінарних зв 'язків: матеріали міжнар. наук.-практ. конф., 9-10 жовт. 2014 р. / редкол. В. Я. Тацій (голов. ред.), В. І. Борисов (заст. голов. ред.) та ін. Х.: Право, 2014. С. 270-273.

34. Дорохіна Ю. А. Теоретичні проблеми кримінально-правової охорони власності в Україні: дис. ... д-р юрид. наук. Запоріжжя, 2017. 527 с.

DOI 10.31558/2518-7953.2019.1.11

УДК 343.2

\author{
I. \\ доцент кафедри конституційного, \\ міжнародного і кримінального права \\ Донецького національного університету \\ імені Василя Стуса, \\ канд. юрид. наук
}

\title{
УМОВИ ПРАВОМІРНОСТІ, ЩО СТОСУЮТЬСЯ ДІЯННЯ ОСОБИ, ЯКА ЗАЗНАЛА ПРИМУСУ \\ (ЗА ЗМІСТОМ СТАТТІ 40 КРИМІНАЛЬНОГО КОДЕКСУ УКРАЇНИ)
}

Ключові слова: примус, обставини, щзо виключають злочинність діяння, діяння особи, яка зазнала примусу, крайня необхідність, обмежена осудність, свобода волі, насильство.

Дослідження обставин, що виключають злочинність діяння, займає важливе місце в науці кримінального права. Традиційно більше уваги приділяється необхідній обороні та крайній необхідності, окреме опрацювання отримали проблеми затримання особи, що вчинила злочин, виконання наказу або розпорядження та виправданого ризику. Водночас наукові проблеми фізичного або психічного примусу як обставини, що виключає злочинність діяння, у кримінально-правовій доктрині висвітлені не повною мірою.

Різні аспекти підстав вчинення діяння у стані фізичного або психічного примусу раніше розглядались у наукових працях Ю. В. Бауліна [1], В. А. Бліннікова [2], О. В. Дегай [3], А. О. Касьяна [4], С. Г. Келиної [5], В. Ю. Рунова [6], Є. Л. Стрельцова [7] та інших авторів. Проте ряд проблемних питань, які вини- 
кають нині при встановленні умов правомірності фізичного або психічного примусу як обставини, що виключає злочинність діяння, майже залишилися поза увагою науковців. Одним з таких питань $є$ визначення умов правомірності, що стосуються діяння особи, яка зазнала примусу.

Слід зазначити, що в науковій літературі було висловлено пропозицію автоматично перенести на примус умови правомірності крайньої необхідності: наявність і реальність насильства або загрози; неможливість уникнути застосування насильства, крім як вчинення необхідного злочину; відповідність фактично заподіяного збитку з тим, який міг би бути спричинений цій особі [8, с. 459]. Такий підхід заснований на буквальному тлумаченні законодавства, проте він не враховує специфіку примусу, повністю зводить його до крайньої необхідності, не дозволяє відмежовувати ці дві самостійні обставини, що виключають злочинність діяння.

Тому вищевказані питання потребують подальших наукових досліджень, особливо в контексті встановлення спільних та відмінних рис між поняттями «фізичний та психічний примус» та «крайня необхідність», розуміння особливостей підстав вчинення діяння у стані фізичного або психічного примусу, оскільки це дасть змогу вдосконалити правозастосування в аспекті розмежування цих понять та визначити правомірність діяння особи, яка зазнала примусу.

Наведене вище вказує на актуальність теми цієї статті та доцільність іiі дослідження.

Метою изього дослідження є виділення особливостей застосування умов правомірності, щуо стосуються діяння особи, яка зазнала примусу (у контексті ст. 40 Кримінального кодексу Украӥни).

Слід зазначити, що автором вже проведені певні дослідження в цій сфері, відповідно, пропонується виходити з того, що кожна обставина, що виключає злочинність діяння, структурно містить у собі два взаємопов'язаних елементи: підставу для вчинення діяння і безпосередньо діяння, вчинюване під впливом цієї підстави. Підставою вчинення діяння, передбаченого ст. 40 Кримінального кодексу України (далі - КК України), є власне фізичний або психічний примус. Діяння особи, яка завдала шкоди правоохоронюваним інтересам, вважатиметься правомірним лише за наявності таких умов: об'єктивних (умови правомірності, що стосуються акту фізичного або психічного примусу); суб'єктивних (умови правомірності, що стосуються діяння особи, яка зазнала примусу).

Отже, для діяння, вчинюваного в стані примусу, характерні такі умови («суб'єктивні»): 1) психічна або фізична неможливість керувати своїми діями (стосується тільки непереборного фізичного примусу); 2) неможливість запобігти шкоді іншими засобами; 3) відповідність заподіяної шкоди відверненій [9, с. 12]. 
Фізична або психічна неможливість керувати своїми діями є першою, ключовою умовою, використовуваною в ході аналізу непереборного фізичного примусу i, відповідно, вимушеного діяння особи. Вона полягає в тому, що певні фізіологічні або психічні причини не дали особі можливості уникнути виконання протиправної вимоги.

У кримінально-правовій літературі містяться вказівки на характерну ознаку непереборного фізичного примусу - екстремальні фізичні перевантаження. Зокрема, А. Н. Ігнатов відзначає, що в результаті непереборного фізичного примусу особа втрачає здатність керувати своєю поведінкою за власною волею, хоча і має фізичну можливість чинити певні дії або утриматися від їх вчинення [10, с. 95]. Дійсно, в ситуації непереборного примусу така можливість залишається у особи лише теоретично. Інакше кажучи, фізично тренована і психічно цілісна людина могла би подолати насильство, але оскільки кожен із нас, на жаль, «не ідеальний», отже, просто не вистачає волі й відповідних фізичних навичок і умінь, щоб уникнути необхідності скоїти злочин.

Аналогічним чином при переборному фізичному примусі особа також піддається впливу надмірних, порівняно зі звичайним життям, перевантажень, проте вони найчастіше є відповідними їі психофізіологічним можливостям. Іншими словами, необхідний якомога більше диференційований підхід до визначення порогу опірності конкретної людини.

Психічний примус в аспекті цієї ознаки нічим не відрізняється від фізичного, за винятком того, що має іншу структуру примусового акту, який складається тільки з вимоги і загрози, втім не містить застосування фізичного насильства, або фактично застосоване насильство є незрівнянно малим, порівняно із загрозою $\mathrm{i}$ необхідним діями.

У ситуації переборного фізичного або психічного примусу особа не може посилатися у своє виправдання на стан примушення у тому випадку, коли на ній лежить правовий обов'язок із запобігання конкретним протиправним вчинкам.

У разі крайньої необхідності коло таких випадків настільки широке, що дозволяє виділяти відповідну особливу умову правомірності. Навпаки, примус можна виключити лише тоді, коли вимоги закону відносно особи були пов'язані 3 наданням їй права і можливості боротися з імовірним застосуванням сили. Отож, до кола таких осіб можна віднести лише окремих військовослужбовців, працівників поліції та інших правоохоронних органів, наділених правоздатністю щодо боротьби з порушеннями громадського порядку, запобігання і припинення злочинів.

У цьому сенсі доволі цікавою видається французька практика. Для інституту необхідності Кримінальний кодекс Франції спеціально вимагає відсутності явної невідповідності між використовуваними засобами захисту і тяжкістю загрози (ст. 122-7 КК Франції), тоді як примус не включає такої вимоги. Проте в ст. 122-2 
КК Франції йдеться про те, що «не підлягає кримінальній відповідальності особа, що діяла під впливом якої-небудь сили або примусу, яким вона не могла протистояти», отже виникає необхідність доводити наявність неможливості протистояти примусу [11]. Аналогічне положення для крайньої необхідності містять також інші КК (наприклад, ч. 5 ст. 21 КК Іспанії) [12]. Відповідно до ст. 2 Закону України «Про Національну поліцію» завданнями поліції $\epsilon$, зокрема, надання поліцейських послуг у сферах: забезпечення публічної безпеки і порядку; охорони прав і свобод людини, а також інтересів суспільства і держави; протидії злочинності; надання в межах, визначених законом, послуг з допомоги особам, які з особистих, економічних, соціальних причин або внаслідок надзвичайних ситуацій потребують такої допомоги [13].

Особливістю психічної сфери людини є їі значний суб'єктивізм, розмитість критеріїв оцінки і перевірки особистих відчуттів. Це зобов'язує приділяти особливу увагу перевірці реальних мотивів особи та можливості уникнути спричинення шкоди. Мотиваційна теорія волі, яка є панівною в психології, перенесена в кримінальне право, найважливішим і найнебезпечнішим елементом якої $\epsilon$ необхідність об'єктивної, тобто a priori не залежної від суб'єкта, оцінки його дій.

За всіх переваг цієї позиції, пов'язаних з обмеженням суб'єктивізму особи, яка застосовує закон, вона не дозволяє зважати повною мірою на специфіку внутрішнього, психічного життя особи. Так, у судовій практиці зустрічаються такі випадки патологічного розладу волі, як клептоманія, піроманія, дромоманія (потяг до постійного змінення занять і місця мешкання) [14, с. 77]. Природно, їх ідентифікація нерідко викликає значні труднощі, проте не можна лише на цій підставі погодитися з позицією окремих учених, що заперечують будь-яку можливість виключення злочинності діяння в таких випадках.

Для цього в кожному конкретному випадку необхідно проводити комплексну судову психолого-психіатричну експертизу. Практика свідчить, що у процесі призначення цих експертиз експертові часто ставлять питання стосовно наявності у підекспертного таких характерологічних рис, як підвищена навіюваність, агресивність, залежність, підкорюваність, лідерство, схильність до фантазування, вигадок. Нерідкі питання про характер і рівень розвитку пізнавальних процесів (розумової діяльності та сприйняття). Ретроспективний характер має визначення у осіб із ознаками психічної патології або таких, що перенесли нервово-психічні ушкодження, виду і глибини емоційних реакцій у той момент, що цікавить слідчого і суд. Психічні патології, навіть неявно виражені, можуть істотно впливати на сприйняття особою ситуації як загрозливої і на ії̈ здатність адекватно реагувати; з-поміж осіб з ненадмірними патологіями особливо варто виділити астеніків, що характеризуються крайньою нервово-психічною збудливістю і зниженою обороноздатністю [15, с. 56-57]. 
Мотиваційна теорія волі не дозволяє адекватно оцінювати і психічне ставлення особи до примусового акту з урахуванням дії стресової ситуації. Так, у КК Іспанії вчинення злочину в стані надмірного страху є самостійною обставиною, що виключає злочинність діяння (ч. 6 ст. 21). Заслуговує на особливу увагу і ст. 6 розділу 24 КК Швеції, згідно з якою особа не повинна нести відповідальність за перевищення меж правомірності окремих обставин, що виключають злочинність діяння, «якщо обставини були такі, що їй важко було встигнути обдумати свої дії» [16]. Видається, що ці положення мають бути сприйняті й вітчизняною кримінально-правовою доктриною в рамках характеристики умов правомірності низки обставин, що виключають злочинність діяння.

Важливе значення має також вік примушуваного. Раніше зазначалося, що неповноліття особи зумовлює застосування до неї більш м'яких критеріїв. При цьому йдеться про неадекватність оцінки неповнолітньою особою протиправної ситуації через недостатній психічний розвиток, а не про дискусійну в науці концепцію «вікової неосудності», хоча означені категорії є близькими.

Загалом, будь-які психічні розлади, що впливають на здатність особи керувати своїми діями, повинні бути враховані в оцінці переборного примусу - це випадки так званої обмеженої осудності. До таких, зокрема, віднесено не лише патології, що є об’ єктом традиційного вивчення судової психіатрії, але і яскраво виражену акцентуацію характеру, тривалі депресивні стани в межах осудності, залежність від наркотиків, алкоголю тощо [17, с. 37].

За обмеженої осудності особа зовні може виглядати цілком нормальною, в цих випадках психіатри нерідко вбачають підстави для застосування ст. 23 КК України.

Як зазначено в медичній літературі, психічна травматизація посилює конституціонально-біологічні особливості істеричної особи, приводить до наростання вмотивованості, навіюваності, поспішності рішень, спроб щонайшвидше зняти емоційне напруження. Поведінка хворих на істеричну психопатію нерідко має афектовану мотивацію без належної оцінки можливих наслідків, що витікає 3 властивої істеричній психопатичній особі трансформації процесу побудови програми поведінки зі зменшеною здатністю прогнозувати наслідки своїх вчинків. Фактично середній психічний стан звичайної здорової людини (так звана норма) значно відрізняється від середнього стану психічно хворої людини, хоча i тут можна знайти певну медіану поведінки, своєрідну норму при патології. Проте особливості вольового зусилля для ініціації діяльності за звичайної та патологічної норм можуть істотно різнитися, не дозволяючи повною мірою застосовувати до хворого традиційні критерії винності [18, с. 88].

Зрештою, психічний стан примушуваної особи повинен вважатися обставиною, що підвищує небезпечність учиненого над особою акту примусу, і навіть 
незначне на погляд здорової людини насильство (зокрема, без прямих погроз) може бути визнане примусом за змістом ст. 40 КК України. Також обов' язково повинно бути враховане перебування підлеглого в стані службової або іншої залежності від особи, яка чинить примус.

У певних випадках примус може викликати у примушуваного стан фізіологічного афекту, що тісно пов’язаний з емоційною діяльністю людини і має не лише психологічне, але і фізіологічне підгрунтя. Вчинення злочину в стані афекту, викликаного діями потерпілого, є пом'якшувальною обставиною і враховується при конструюванні привілейованих складів злочинів проти життя або здоров'я особи.

Окрім афекту, виділяють також інші, більш тривалі порушення емоційного життя людини; двома крайніми станами визнають тяжку депресію і маніакальний стан. Як наголошено в психіатричній літературі, найбільш типовим і вираженим розладом емоції є маніакально-депресивний психоз, розповсюдженість якого досягає, за різними оцінками, 0,7-2 на 1000 осіб населення, а загальне число осіб, що виявляють емоційні розлади, сягає 10-15 \% населення [19, с. 101]. Якщо афект був викликаний примусом, то він повинен не лише бути врахований при визначенні покарання, але і впливати на розв'язання питання про винуватість особи.

Хоча фізіологічного афекту і можна запобігти посиленим вольовим контролем на початковій стадії, проте психотравматична ситуація примусу знижує можливість особи контролювати свою поведінку. Тому виникнення у особи цього стану в результаті примусу вже як таке може бути однією з головних підстав для визнання в їі діях переборного психічного примусу. Про непереборність примусу в момент афекту навряд чи може йтися, оскільки обмежені можливості контролю своїх дій у особи все ж зберігаються.

Таким чином, оцінка разом із іншими об'єктивними чинниками неповноліття і некритичних психічних розладів, а також наявність стану афекту істотно впливають на кваліфікацію примусу, створюючи привілейовані умови для визнання особи як такої, що перебувала в стані примусу, за ст. 40 КК України.

Другою умовою правомірності, що характеризує діяння особи, яка зазнала примусу, є неможливість відвернути шкоду іншими «засобами». Ця умова зумовлена об'єктивними ознаками вчиненого - зокрема, часом, місцем вчинення злочину, обстановкою, способом і характером насильства, наслідками, що загрожують особі, наявністю і небезпечністю знарядь посягання.

Наявність у особи можливості уникнути заподіяння шкоди у стані примусу передбачає, щоб вона мала альтернативу незлочинної поведінки. Якщо особа могла уникнути примусу, це не є підставою для визнання наявності стану примусу.

Оскільки примус завжди викликаний діями людини, то, відповідно, у особи, яку примушують, виникає право на необхідну оборону. Проте необхідна оборо- 
на є правом, а не обов'язком особи, тому цю особу не можна притягати до відповідальності за те, що вона не скористалася зазначеним правом.

Можливість дій особи у межах необхідної оборони передбачає наявність альтернативи - відвернути шкоду іншими «засобами». Однак ця альтернатива не повинна впливати на правомірність діяння особи, вчиненого під безпосереднім впливом фізичного або психічного примусу.

Третя умова правомірності, що характеризує діяння особи, яка зазнала примусу, це співрозмірність завданої та відверненої шкоди. Об'єктом заподіяння шкоди в ситуації фізичного або психічного примусу є охоронювані законом інтереси особи (життя, здоров'я, власність), суспільні інтереси (громадська безпека, громадський порядок, безпека руху транспорту) або інтереси держави (недоторканність державних кордонів, збереження державної таємниці, авторитет влади, порядок управління).

Співрозмірність у цьому випадку означає, що шкода від вчиненого діяння має бути меншою за ту, що загрожує особі. Доволі просто це зрозуміти в ході аналізу посягання на один і той самий об'єкт кримінально-правової охорони якщо життю особи загрожує небезпека, вона має право завдати шкоди здоров'ю іншої людини. Якщо йдеться про посягання на різні об'єкти кримінально-правової охорони, то питання про співрозмірність завданої шкоди необхідно розглядати залежно від ієрархї̈ власне об'єктів кримінально-правової охорони.

Найбільш цінними об'єктами кримінально-правової охорони слід вважати життя і здоров’я окремої особи саме через те, що їх неможливо відновити.

У радянській кримінально-правовій літературі зазначалося, що вчинення під впливом примусу (в умовах крайньої необхідності) злочину проти держави не виключає злочинності діяння, проте може лише слугувати підставою для пом'якшення покарання [20, с. 230]. Наразі, як відомо, пріоритети змінилися - найвищими соціальним цінностями нині визнано саме названі вище суспільні відносини, що підлягають охороні законом про кримінальну відповідальність.

На основі проведеного дослідження можна зробити такі висновки:

1. При встановленні умов правомірності, щуо характеризують діяння особи, яка зазнала примусу, потрібно брати до уваги (разом із іншими об'єктивними чинниками) неповноліття, некритичні психічні розлади, наявність стану афекту. Це може істотно впливати на кваліфікацію примусу, створюючи привілейовані умови для визнання особи як такої, щзо перебувала в стані примусу за ст. 40 КК України.

2. При визначенні такої умови правомірності, щуо характеризує діяння особи, яка зазнала примусу, як «неможливість відвернути икоду іншими «засобами» необхідно надавати оцінку об'єктивним ознакам вчиненого. Однак при цуьому виникнення у особи можливості дій у межах необхідної оборони не повинно 
впливати на правомірність діяння особи, вчиненого під безпосереднім впливом фізичного або психічного примусу.

3. При виріменні питання про співрозмірність завданої та відверненої икоди при оцінці діяння примушуваної особи необхідно виходити з ієрархії об'єктів кримінально-правової охорони.

Врахування наведених положень надасть визначеності при здійсненні кримінально-правової кваліфікації вчинених під примусом діянь. Поряд із цим питання щодо змісту умов правомірності, що стосуються діяння особи, яка зазнала примусу (у контексті ст. 40 КК України) мають стати предметом подальших наукових досліджень.

1. Баулин Ю. В. Обстоятельства, исключающие преступность деяния: монография. Харьков: Основа, 1991. 360 с.

2. Блинников В. А. Система обстоятельств, исключающих преступность деяния, в уголовном праве России: дис. ... д-ра юрид. наук: 12.00.08. Нижегор. акад. МВД России. Н. Новгород, 2002. $403 \mathrm{c}$.

3. Дегай О. В. «Крайняя необходимость» и «физическое или психическое принуждение» как обстоятельства, исключающие преступность деяния: вопросы соотношения. Современные актуальные вопросы государства, права и юридического образования: материалы Всерос. научно-практ. интернет-конференции / Отв. ред. В. М. Пучнин. Тамбов: Першина, 2008. С. 135-140.

4. Касьян А. О. Фізичний та психічний примус в кримінальному праві України: дис. ... канд. юрид. наук: 12.00.08. Харків. нац. ун-т внутр. справ. Харків, 2015. 160 с.

5. Келина С. Г. Обстоятельства, исключающие преступность деяния: понятие и виды. Уголовное право. 1999. № 3. С. 3-8.

6. Рунов В. Ю. Кримінально-правова охорона особи від незаконного примусу: автореф. дис. ... канд. юрид. наук: 12.00.08. Нац. акад. наук України, Ін-т держави i права ім. В. М. Корецького. К., 2013. 20 с.

7. Стрельцов Є. Л., Орловський Б. М. Обставини, що виключають злочинність діяння при захисті від суспільно небезпечного посягання: напрямки удосконалення кримінально-правового регулювання: монографія / за заг. ред. С. Л. Стрельцова. Одеса: Фенікс, 2014. 385 с.

8. Курс российского уголовного права. Общая часть / Рос. акад. наук, Ин-т гос-ва и права; [сост.: Бородин С. В. и др.]; под ред. В. Н. Кудрявцева, А. В. Наумова. М.: Спарк, 2001. 767 с.

9. Жданова I. Є. Фізичний або психічний примус як обставина, що виключає злочинність діяння: автореф. дис. ... канд. юрид. наук: 12.00.08. Нац. акад. внутр. справ. Київ, 2014. 20 с.

10. Игнатов А. Н., Красиков Ю.А. Курс российского уголовного права: в 2 т. М.: НОРМА ИНФРА-М, 2001-2002. Том 1: Общзая часть. 2001. 549 с.

11. Станіч В. С. Кримінальний кодекс Французької Республіки / під ред. В. Л. Менчинського; пер. К. І. Мазуренко. Київ: ОВК, 2017. 348 с.

12. Станіч В. С. Кримінальний кодекс Королівства Іспанія / під ред. В. Л. Менчинського; пер. О. В. Лишевської. Київ: ОВК, 2016. 284 с.

13. Про Національну поліцію: Закон України від 2 липня 2015 р. № 580-VIII. Вiдомості Верховної Ради Украӥни. 2015. № 40-41. Ст. 379. (Із змінами).

14. Марчук А. І. Судова психіатрія: навчальний посібник. Київ: Атіка, 2003. 240 с.

15. Кудрявцев И. А. Судебная психолого-психиатрическая экспертиза. Москва: Юрид. лит., 1988. 224 с.

16. Уголовный кодекс Швеции / науч. ред. Н. Ф. Кузнецова, С. С. Беляев; пер. С. С. Беляева. СПб.: Юридический центр Пресс, 2001. 304 с. 
17. Ситковская О. Д. Психологический комментарий к отдельным статьям Уголовного кодекса Российской Федерации (части Общая и Особенная). Москва: Акад. Генеральной прокуратуры Российской Федерации, 2009. 180 с.

18. Семке В. Я. Истерические состояния. Москва: Медицина, 1988. 224 с.

19. Шевченко А. Є., Соловйова В. В., Стрельник О. Л. Обставини, що виключають юридичну відповідальність: монографія. Донецьк: Юго-Восток, 2011. 177 с.

20. Беляев Н. А. Курс советского уголовного права. Часть Общая / отв. ред. Н. А. Беляев, М. Д. Шаргородский. Том 1. Л.: Изд-во ЛГУ, 1970. 868 с.

DOI 10.31558/2518-7953.2019.1.12

УДК 343.131

\author{
I. А. Щербак \\ доцент кафедри конституційного, \\ міжнародного і кримінального права \\ Донецького національного університету \\ імені Василя Стуса, \\ канд. юрид. наук, доцент
}

\title{
ПРОБЛЕМНІ АСПЕКТИ ПРОЦЕДУРИ ПОВІДОМЛЕННЯ ПРО ПІДОЗРУ В КОНТЕКСТІ РЕАЛІЗАЦІЇ ПРИНЦИПУ ВЕРХОВЕНСТВА ПРАВА
}

Ключові слова: кримінальне провадження, повідомлення про підозру, принции верховенства права, права і свободи людини, окремі категорії осіб.

Згідно зі ст. 8 Кримінального процесуального кодексу України (далі - КПК України) кримінальне провадження здійснюється з додержанням принципу верховенства права, відповідно до якого людина, її права та свободи визнаються найвищими цінностями та визначають зміст і спрямованість діяльності держави.

Складність і багатогранність категорії верховенства права значно ускладнює будь-яку спробу сформулювати універсальне визначення цього поняття, прийнятне для усіх галузей права, для усіх життєвих ситуацій [1, с. 7]. Однак, потрібно погодитись 3 провідними спеціалістами цієї сфери в тому, що зазначений принцип є базовим, адже він визначає умови та спосіб побудови і діяльності правової системи взагалі, а також її окремих складових - галузей права, у тому числі й кримінально-процесуального права [2, с. 516].

Зміст верховенства права науковцями традиційно зводиться до двох основних концепцій: «формальної» та «матеріальної» (змістовної) [3, с. 162-169]. Формальний аспект полягає у тому, що в суспільстві мають існувати правові норми, яких дотримуються всі суб'єкти, у тому числі й держава. Норми мають бути зрозумілими, чіткими, ясними і несуперечливими, доступними, і зазвичай не мати 